\title{
Mechanical Response of Shear Connectors in Steel-Concrete Composite Beams with Steel Boxes and Precast Decks
}

\author{
Jiuqun Mao ${ }^{1}$, Jiazhi Zhuang ${ }^{2}$, Peng Duan ${ }^{1, *}$, Yingkun $\mathrm{Xie}^{3}$ and Mingzhen $\mathrm{Li}^{4}$

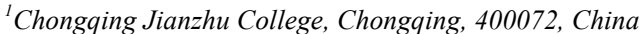 \\ ${ }^{2}$ Chongqing Architectural Design Institute of China, Chongqing, 400015, China \\ ${ }^{3}$ Chongqing Chuandongnan Geological Engineering Survey and Design Institute, Chongqing, 400030, China \\ ${ }^{4}$ Department of Electrical Engineering, Wayne State University, Detroit, MI 48202, United States
}

Received 1 December 2018; Accepted 20 February 2019

\begin{abstract}
The steel-concrete composite beam with steel box and precast deck is a new bridge structure. However, studies on the mechanism of a steel box and precast concrete slab connected by a shear key remain scarce. To explore the mutual coupling relationship between the steel box girder and the prefabricated bridge deck slab under a shear key, an experimental model of shear connection between steel box and precast concrete slab was proposed in this work. Finite element analysis and experimental methods were used to develop a push-out test analysis model with 12 symmetrical Ushaped shear keys in three rows and two columns along the longitudinal direction of a precast slab. Using the plastic damage model, the mechanical response characteristics of the shear connection structure, including its force transmission mechanism, stress state, and strain distribution, were analyzed and the accuracy of the calculation results was verified. Results indicate that as the amount of load increases, the compressive stress of the concrete slab expands from the root of the shear key in an arched manner and eventually forms an elliptical table. The load on a single shear key is inversely proportional to its distance from the loading point. The crack load of the concrete slab is $0.47 \mathrm{Pu}$, and the yield load of the shear key is $0.7 \mathrm{Pu}$. This study offers a certain reference value for optimizing the design of bridges with a steelconcrete composite girder.
\end{abstract}

Keywords: steel-concrete composite beam; shear key; finite element; mechanical response

\section{Introduction}

The steel-concrete composite beam with steel box and precast deck is a new structure that offers several advantages, including its better bearing capacity, ductility, seismic performance, and fire performance compared with typical steel structures [1]. Therefore, this structure can meet the large span, large load, and bearing bad environment requirements in modern bridge construction and building industrialization technology. Given these benefits, this structure has been widely developed and used in China for more than a decade [2]. The interaction between the steel box and concrete in reinforced concrete during the stress process can significantly improve the strength, plasticity, and toughness of these materials [3]. The presence of core concrete [4] delays or even prevents the local buckling of the steel structure, thereby ensuring the advantages of various materials. Using the steel box as a template for concrete construction not only saves costs but also accelerates the construction process. The bridge deck is generally constructed by using a cast-in-place concrete. The prestress is born by the steel box girder and bridge deck after prestressed tensioning, thereby limiting the prestress of the bridge deck and forming cracks in the negative moment area.

\footnotetext{
*E-mail address: ii_qiao@163.com

ISSN: 1791-2377 @ 2019 Eastern Macedonia and Thrace Institute of Technology. All rights reserved. doi:10.25103/jestr.121.19
}

The concrete bridge deck can also be prefabricated to increase the prestress on the bridge deck. After installing the prefabricated bridge deck on the steel box, longitudinal prestressing can be applied to longitudinally connect the precast concrete bridge deck as a whole and to reproduce the concrete of the reserved hole. In this way, the upper flange of the steel box girder and bridge deck can be consolidated. The shear key can determine whether this scheme can be implemented in coordinating the steel-concrete composite beam with steel box and precast deck.

Although scholars have examined the mechanical properties of the steel-concrete composite beam shear key [5-8], their findings on the correlation between the shear key and steel and concrete materials deviate from the actual working state. Therefore, an accurate evaluation of the mechanical behavior of the shear key of steel-concrete composite beam with steel box and precast deck can help address urgent problems and shed light on the mutual coupling relationship between the steel box girder and the prefabricated bridge deck under the shear force bond.

On the basis of the plastic damage model, finite element analysis and experimental methods were used in this study to develop an experimental model of the shear connection between steel box and precast concrete slab. The force transfer mechanism, stress state, and strain distribution of the coupling structure were analyzed to accurately evaluate the mutual coupling relationship between the steel box girder and the prefabricated bridge deck under the shear 
Jiuqun Mao, Jiazhi Zhuang, Peng Duan, Yingkun Xie and Mingzhen Li/

Journal of Engineering Science and Technology Review 12 (1) (2019) 163 - 172

force bond as well as to provide references for optimizing the design of steel-concrete composite girder bridges.

\section{State of the art}

Scholars have studied the shear key of steel-concrete composite beams. For instance, Shim [9] found that the crack resistance of cast-in-place holes was weaker than that of precast concrete bridge plates in a test composite beam with a reserved hole for the shear connection. However, the test analysis was still deficient. Based on the perfobond leiste(PBL) shear key, Liang [10] developed the perfobond hoop(PBH) shear key of a perforated stiffener ferrule for a steel box-concrete combination structure and then determined the reduction factor of the group bearing capacity of the PBH shear key. However, the PBL shear key was not compared comprehensively. Lin [11] examined the force mechanism and deformation characteristics of a shearing nail and then developed a shear stiffness calculation formula for calculating the shearing force of the shearing nail. However, this formula is not applicable to a U-shaped shearing key. By analyzing the force mechanism and ultimate bearing capacity of a shearing nail in a combined state, Chen [12] found that the compression of concrete benefits the shearing at the root of a shearing nail. However, an anti-slip analysis of a shearing nail was not conducted. Bing et al. [13] developed a formula for calculating the shear capacity of a PBL shear key while considering lateral prestress yet failed to analyze its deformation characteristics. Shim [14] examined the static strength of shear studs and shear connectors (with diameters exceeding $25 \mathrm{~mm}$ ) that serve as a basis for the design and application of largediameter shear studs in an assembled composite beam. However, the displacement difference distribution was not thoroughly examined. Based on various specifications, Shanpo [15] compared the advantages and disadvantages of the methods for calculating the bearing capacity of stud shear connectors. However, the methods for calculating stiffness value were not examined. Breuninger et al. [16] highlighted some differences in the shear performance of shear studs in a composite beam for vertical and horizontal distributions. By combining finite element simulation and testing methods, Milan [17] examined the residual bearing capacity of the shear-peg connection under the action of a longitudinal shear force cycle and then proposed a formula for calculating residual bearing capacity. However, the stress state of the residual bearing capacity was not examined. In their test of the shear capacity of high-strength mortar group nail joints, Qingtian et al. [18] found that the arrangement of shearing studs can significantly influence the shear bearing capacity of group studs and that the number of studs is inversely proportional to the average decrease in the bearing capacity of a single nail. However, they did not examine the slip distribution. By testing the shear performance of shear studs in early strength concrete, Topkaya [19] found that cyclic loading only slightly affects the load-slip curve of the test piece. However, this finding does not apply to the Ushaped shear key. Aimin et al. [20] performed a direct shear test by using a shear key, which is commonly utilized as a joint form in designing prefabricated bridge joints, and then developed a formula for calculating shear capacity. However, they did not analyze bending shear without the combined action of bending and shear force. By analyzing the load values and related influencing factors, Wenbiao [21] developed a formula for calculating the ultimate bearing capacity of an embedded PBL shear key. However, the limit state of bearing capacity without the through-reinforcing bar on the shear key was not studied. Sen [22] developed a formula for measuring the bond-slip relationship between the dry and wet bond interfaces of an fiber reinforced polymer(FRP) profile-concrete composite beam by regressing their test data. However, the influence of stiffener support on the overall bending stiffness and bearing capacity of the composite beam was not examined. Classen [23] derived the constraints for the equidistant arrangement of a T-shaped steel beam shear key by performing a finite element numerical analysis but did not conduct the necessary experiments. Lowe [24] performed an experimental study on the load-slip condition of shearconnected shear connectors under varying conditions and observed an uneven concrete stress distribution near the shear pin. Specifically, while the stress value on the pressure side was large, that on the tension side was relatively small. However, this conclusion does not apply to rigid shear keys.

Scholars have also explored the mechanical properties of steel-concrete composite beam shear keys. However, given that the steel-concrete composite beam with steel box and precast deck is a relatively new structure, very few studies have analyzed the mechanical response of its shear key structure. On the basis of the plastic damage model, finite element analysis and experimental methods were combined in this work to establish the experimental model of the shear force coupling structure. In the push-out test, $12 \mathrm{U}$-shaped rigid shear keys were arranged in 3 rows and 2 columns along the longitudinal direction of the prefabricated plate. The mechanical response characteristics, including force transmission mechanism, stress state, and strain distribution, were also examined. The study offers a certain reference value for optimizing the design of bridges with steelconcrete composite girders.

The rest of this study is organized as follows. Section 3 mainly discusses the method for developing the shear coupling structure model. Section 4 analyzes the mechanical response characteristics, including the force transfer mechanism, stress state, and strain distribution of the finite element model, of the shear force connection structure based on the plastic damage model. Section 5 summarizes the findings and draws relevant conclusions.

\section{Methodology}

\subsection{Engineering background}

By taking a steel-concrete composite continuous rigid frame bridge as the engineering background, the upper part of the main bridge is a combined structure of an assembled steel box and prestressed concrete as shown in Figure 1. The shear-bonding structure is a U-shaped shear key. The shearing key has a height of $220 \mathrm{~mm}$, length of $220 \mathrm{~mm}$, thickness of $20 \mathrm{~mm}$, and widths of $100 \mathrm{~mm}$ and $500 \mathrm{~mm}$ along the bridge and upper flange of the steel box, respectively. The distance between the outer edge of the joint and the edge of the steel flange plate is $8.5 \mathrm{~cm}$, the distance from the outer edge of the joint to the edge of the concrete wing is $234.5 \mathrm{~cm}$, and the thickness of the concrete cover on top of the joint is $230 \mathrm{~mm}$. The arrangement of the U-shaped shear keys is shown in Figure 2.

\subsection{Plastic damage model}

ABAQUS was used for the numerical simulation. The concrete plastic damage model was built as a continuous 
medium damage model based on the models of Lubliner and Lee-Fenves [25]. The plastic behavior of the concrete was simulated in an isotropic damage elastic form combined with tensile and compressive plasticity. The model can be applied to one-way, cyclic, and dynamic loading and demonstrates good convergence.

The strain rate for the concrete plastic damage model can be computed as:

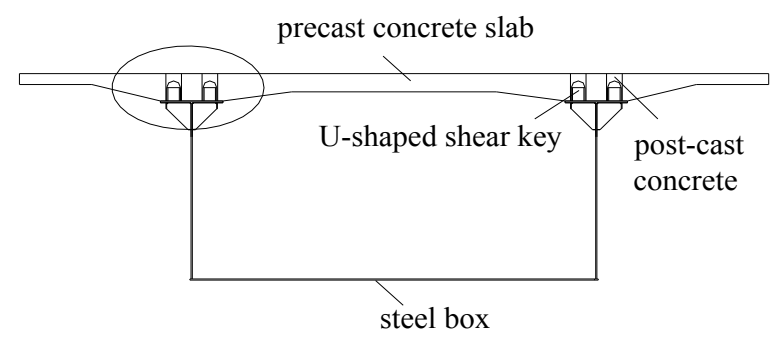

Fig. 1. Schematic diagram of a typical section

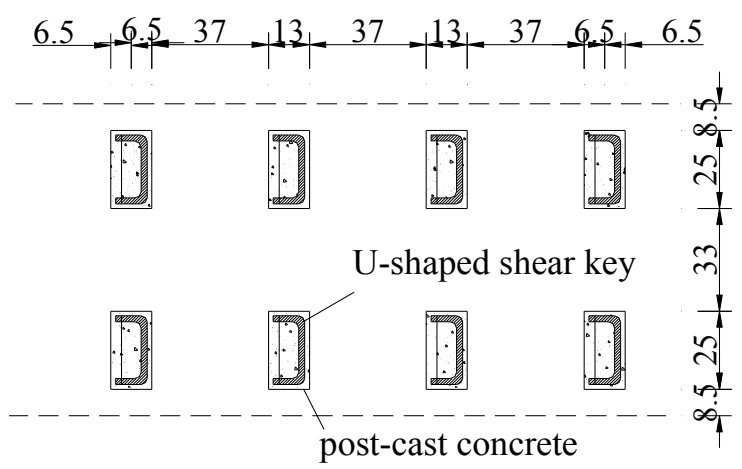

Fig. 2. Arrangement of shear keys (unit: $\mathrm{cm}$ )

\subsection{Plastic damage model}

ABAQUS was used for the numerical simulation. The concrete plastic damage model was built as a continuous medium damage model based on the models of Lubliner and Lee-Fenves [25]. The plastic behavior of the concrete was simulated in an isotropic damage elastic form combined with tensile and compressive plasticity. The model can be applied to one-way, cyclic, and dynamic loading and demonstrates good convergence.

The strain rate for the concrete plastic damage model can be computed as:

$$
\dot{\varepsilon}=\dot{\varepsilon}^{\mathrm{el}}+\dot{\varepsilon}^{\mathrm{pl}}
$$

where $\dot{\varepsilon}$ is the total strain rate, $\dot{\varepsilon}^{\mathrm{el}}$ is the elastic strain rate, and $\dot{\varepsilon}^{\mathrm{pl}}$ is the plastic strain rate.

Meanwhile, the relationship between stress and strain in the concrete plastic damage model can be computed as

$\sigma=(1-d) D_{0}^{\mathrm{el}} /\left(\varepsilon-\varepsilon^{\mathrm{pl}}\right)=D^{\mathrm{el}} /\left(\varepsilon-\varepsilon^{\mathrm{pl}}\right)$

where $\sigma$ is the stress, $\varepsilon$ is the strain, $\varepsilon^{\mathrm{pl}}$ is the plastic strain, $D_{0}^{\mathrm{el}}$ is the initial (undamaged) elastic stiffness of the material, $D^{\mathrm{el}}$ is the elastic stiffness after damage, and $d$ is the stiffness damage variable where $0 \leq d \leq 1$. This variable takes a value of $d=0$ when the material is not damaged and $d=1$ otherwise.

\subsection{Push-out test}

If the model adopts the actual cross-section form that comprises precast concrete slabs, steel boxes, and shearing keys, then its structure becomes highly complex. Moreover, the cross-section is larger than the shear key, and the mesh generation is rough. To simplify the calculation model, the local performance of the shear key was evaluated via amplification analysis while maintaining its force performance. The prefabricated plate was $320 \mathrm{~cm}$ and 1.5 long in the horizontal and longitudinal directions of the joint between the steel box and precast concrete slab, respectively (Figure 1). The upper flange of the steel box connected to the shear key was replaced with an I-beam, and the concrete slab was symmetrically arranged on the other side of the Ibeam to form a balance system. The shearing key of the upper and lower flanges of the beam was connected to the prefabricated concrete bridge deck. A push-out test of the local section shear key was then simulated. The section of the simplified model is shown in Figure 3. The prefabricated panel was $1.5 \mathrm{~m}$ long in the longitudinal direction. A total of 12 shear keys were symmetrically arranged in three rows, with each row having two shear keys.

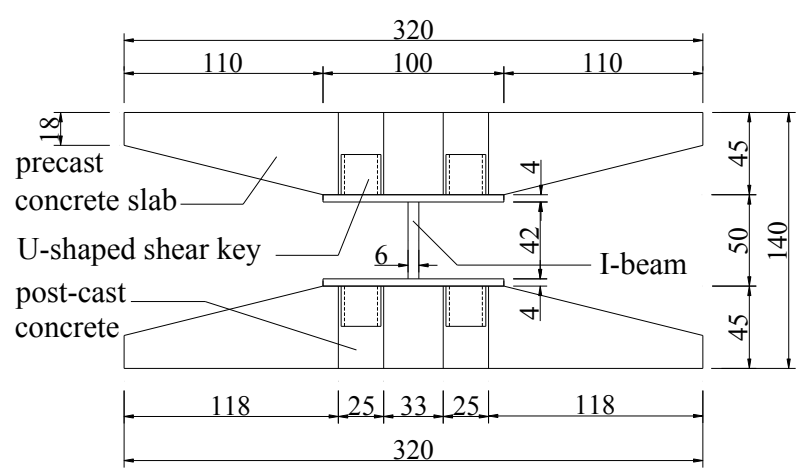

Fig. 3. Dimensions of the simplified model section (unit: $\mathrm{cm}$ )

A thick steel plate should be placed on the loaded I-beam in the shearing force push-out test to ensure a uniform distribution of the load on the I-beam. A thick steel plate was then placed on the loading part of the I-beam, and its loading calculation diagram is shown in Figure 4.

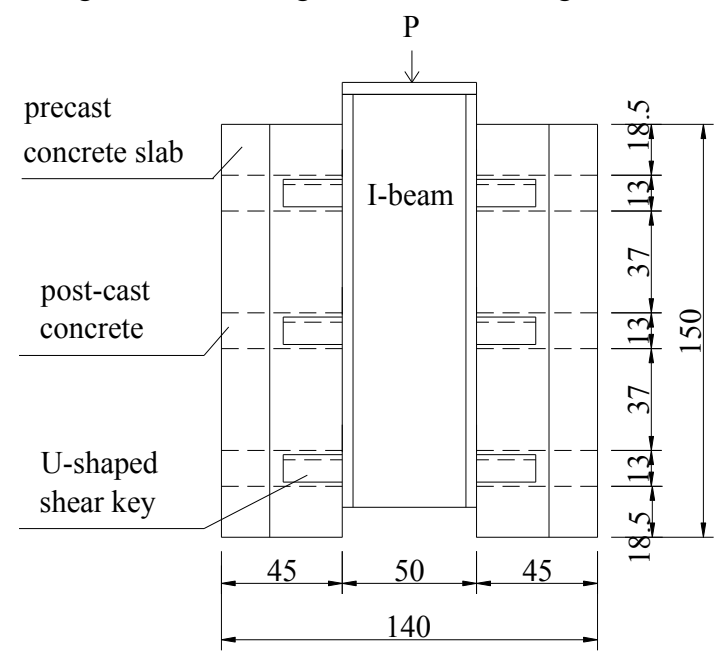

Fig. 4. Loading diagram 
Jiuqun Mao, Jiazhi Zhuang, Peng Duan, Yingkun Xie and Mingzhen Li/

Journal of Engineering Science and Technology Review 12 (1) (2019) 163 - 172

\subsection{Finite element numerical simulation}

A finite element numerical simulation was performed via ABAQUS to simulate the force characteristics of the shear force joint structure. The concrete was simulated with a C3D8R unit, and the connection between the shear key and upper and lower flanges of the I-beam was simulated through "Tie." The shear key was "embedded" into the filled concrete to simulate the connection between the shear key and concrete plate. Given the size of the model and the connections between its components, the meshes were refined in the U-shaped shear key region of the model to explore the rigid shear key and its surrounding mechanical properties.

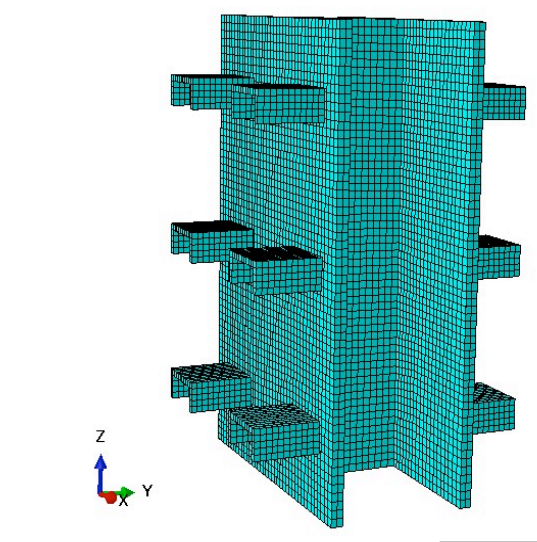

Fig. 5. Finite element model

\section{Result Analysis and Discussion}

\subsection{Analysis of the force transmission mechanism of the shear key}

Increasing the load to $19025 \mathrm{kN}$ would lead to the failure of the shear key failed and damage the components. Therefore, the shear capacity of the shear key was set to $P u=19025 \mathrm{kN}$. The force transmission mechanism of the shear keys was examined by analyzing their stress nephograms. Meanwhile, the force mechanism along the force direction was examined based on the stress nephogram of the bottom surface of the concrete slab and I-beam as well as the section of the concrete slab along the vertical centerline. The force mechanism along the height of the shear key was studied based on the stress nephogram of the concrete slab crosssection. Figures 6,7 , and 8 present the stress nephograms of the bottom surface of the concrete slab and I-beam under $0.21 \mathrm{Pu}$, the section of the concrete slab along the vertical centerline, and the concrete slab cross-section.

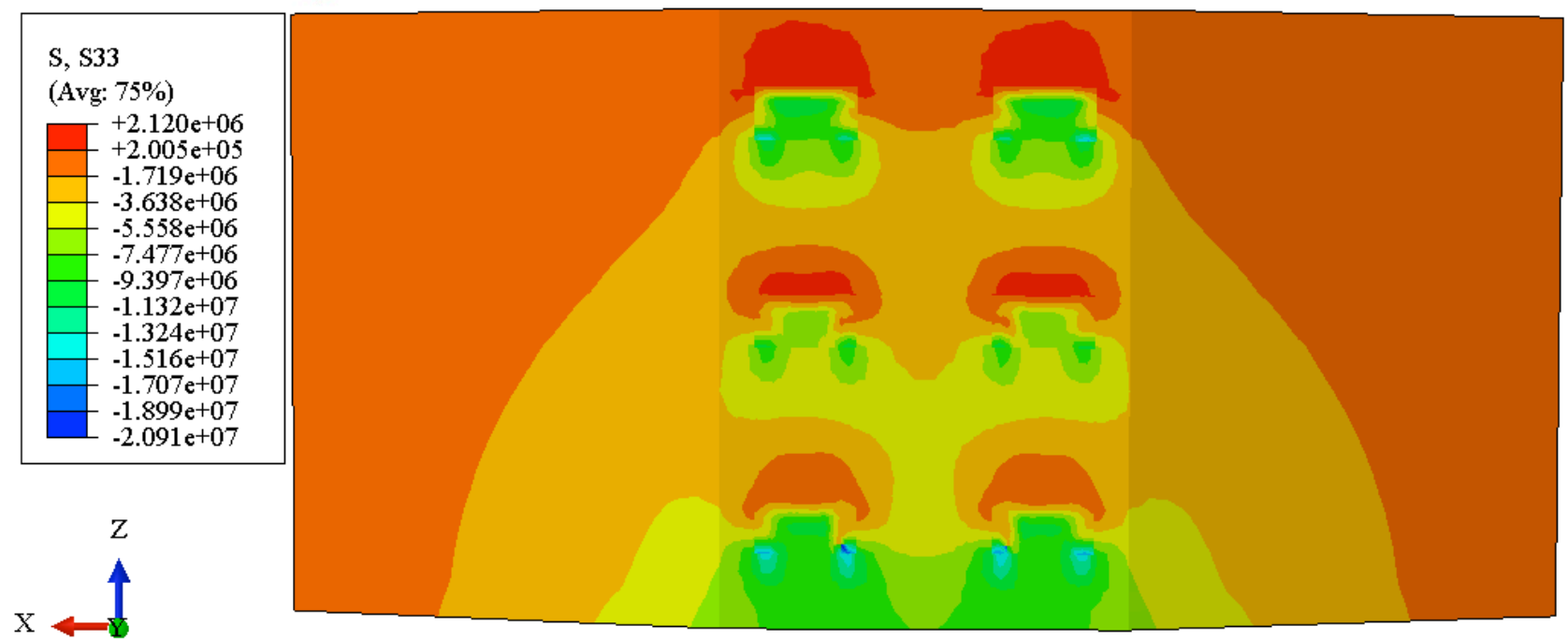

Fig. 6. Stress nephogram of the bottom surface of the concrete slab and I-beam

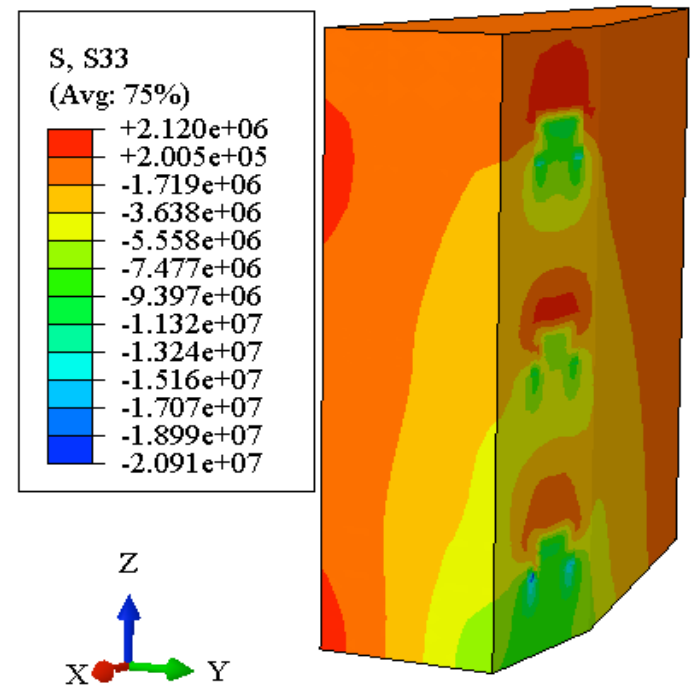

Fig. 7. Stress nephogram of the section of the concrete slab along the vertical centerline 


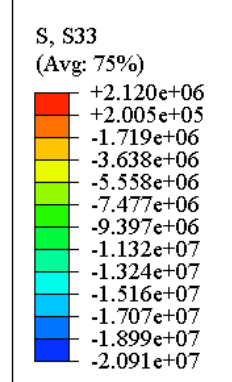

Fig. 8. Stress nephogram of the concrete slab cross-section

When no load was applied, the shear key bonded to the infusion material and embedded into the reserved hole of the shear key of the prefabricated plate. After its application, the load was transmitted to the shear key through the I-beam and was transferred to the concrete from top to bottom. Figures 6 to 8 show that the load is initially transmitted to the root region of the shear key. In this case, the concrete at the bottom of the shear key was subjected to a large amount of pressure and the bearing area was small. As the load increased, the compressive stress of the concrete slab gradually increased from the root of the shear key in an arched manner and eventually formed an elliptical table.

Figures 9 and 10 present the stress nephograms of the filling material along the opening direction of the shear key and the direction opposite to the opening direction of the shear key.
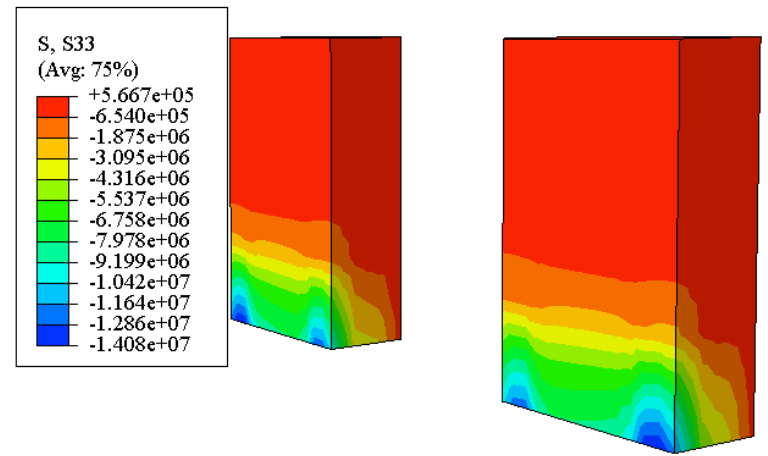

Fig. 9. Stress nephogram of the filling material along the opening direction of the shear key
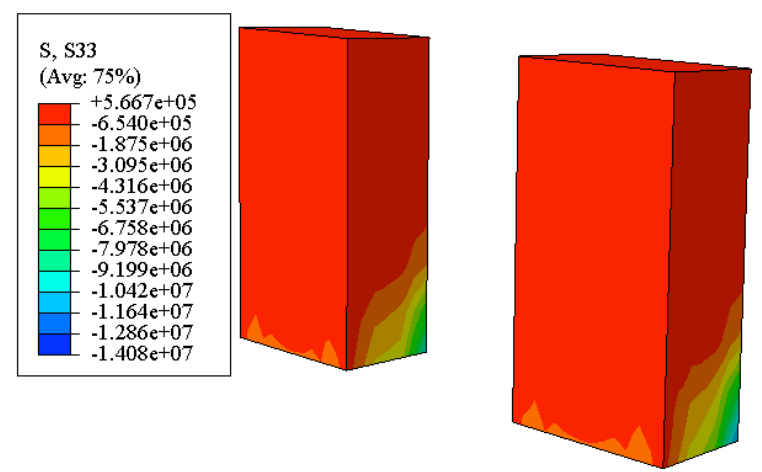

Fig. 10. Stress nephogram of the filler material in the direction opposite to the opening direction of the shear key

The above figures show that the I-beam transmits the load to the concrete through the shear key in the opening direction and that the concrete is locally pressed. The maximum stress was observed in the contact area between the shear key tip and concrete. Given the small section of the shear key tip, the concrete compression area in the contact area was relatively small. As the load increased, the stress gradually spread from the root of the shear key along with the height. The concrete opposite to the opening direction of the shear key had a low amount of stress. However, this stress value increased along with the load to prevent an increase in the compressive stress of the concrete in front of the shear key. Figure 11 presents the stress nephogram of the shear key.
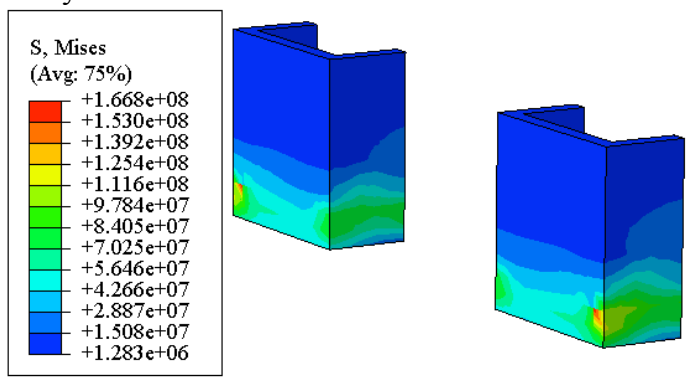

Fig. 11. Stress nephogram of the shear key

As can be seen above, the largest stress was recorded on the contact surface between the shear key and I-beam. The stress at the root of the shear key gradually moved upward as the load increased.

Figure 12 presents the stress cloud diagram of each shear key on the I-beam. After the transmission of shear force in the upper, middle, and lower rows of shear keys, the largest and smallest loads were observed at the lower and middle shear keys, respectively. The load on a single shear key was inversely proportional to the distance to the loading point because the upper and lower shear keys were located close to the loading point while the middle shear key was located far from the loading point.

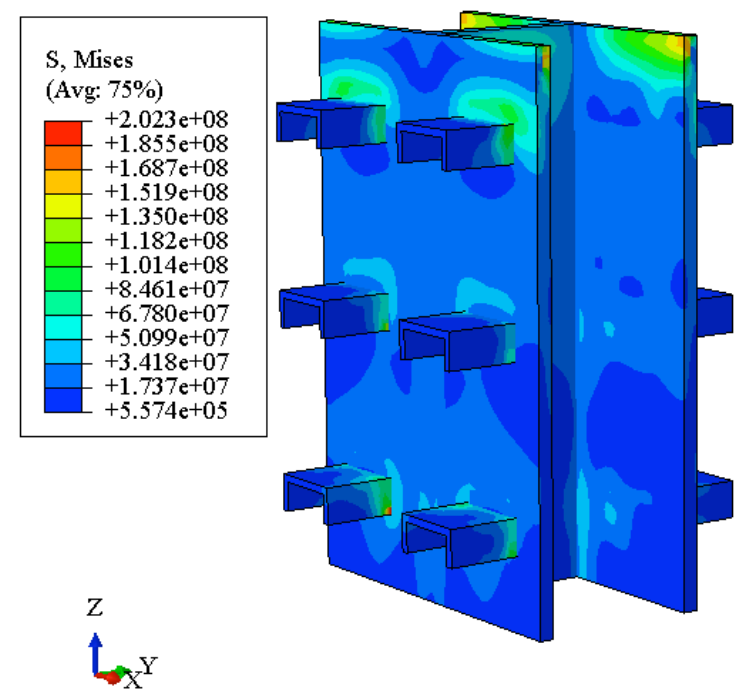

Fig. 12. Stress nephogram of each shear key 
Jiuqun Mao, Jiazhi Zhuang, Peng Duan, Yingkun Xie and Mingzhen Li/

Journal of Engineering Science and Technology Review 12 (1) (2019) 163 - 172

The stress distribution on the concrete plate is shown in Figure 13.

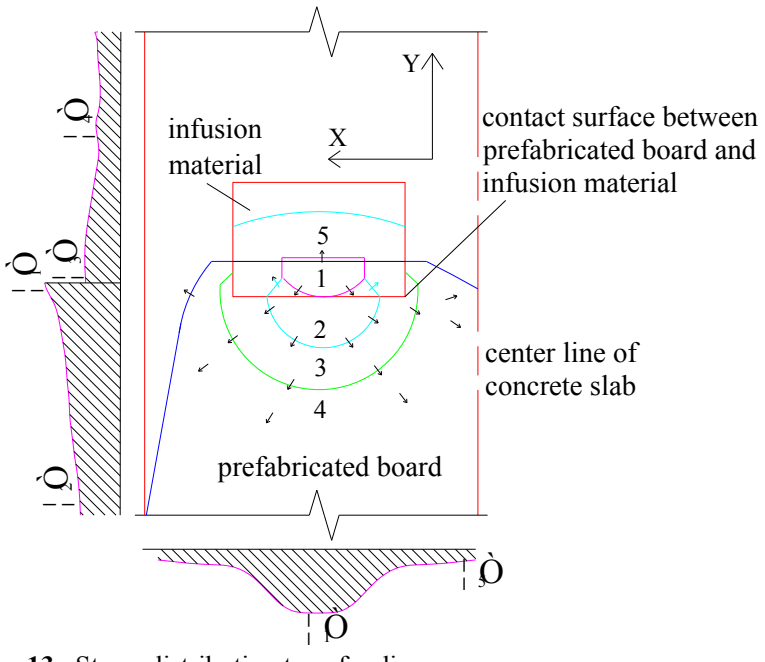

4.2 Analysis of the Stress State of the Shear Connection Structure

\subsubsection{Stress state of the concrete slab during cracking}

The load size reached $9000 \mathrm{kN}$ as the main tensile stress of the concrete reached $2.66 \mathrm{MPa}$. At this point, the cracking load of the shear key was Pcr $=9000 \mathrm{kN}$, that is, the concrete slab was cracked when loaded to $0.47 \mathrm{Pu}$. The main tensile stress diagram of the concrete slab under the cracking load Pcr was then examined

Fig. 13. Stress distribution transfer diagram

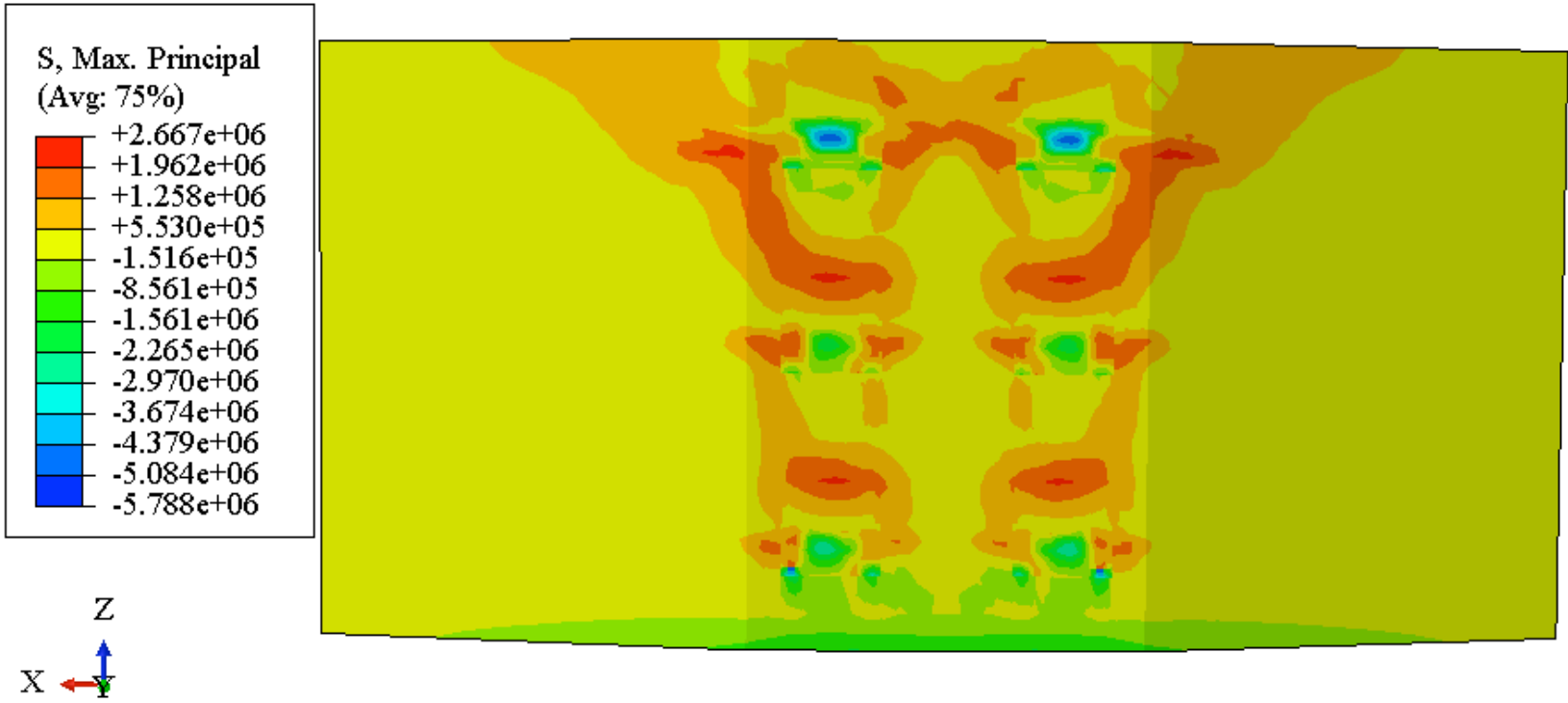

Fig. 14. Main tensile stress nephogram of the bottom contact surface of the concrete slab and I-beam

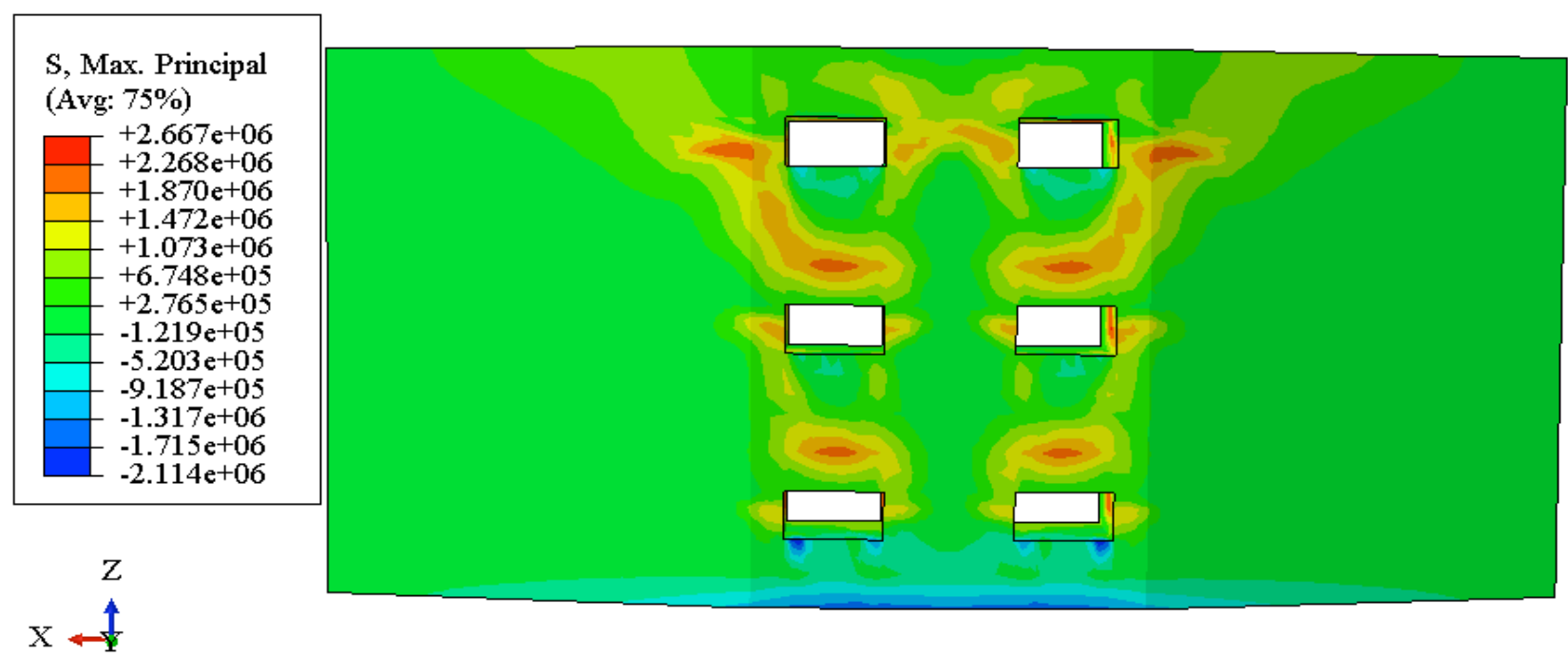

Fig. 15. Stress nephogram of the bottom contact surface of the concrete slab and I-beam 
Jiuqun Mao, Jiazhi Zhuang, Peng Duan, Yingkun Xie and Mingzhen Li/

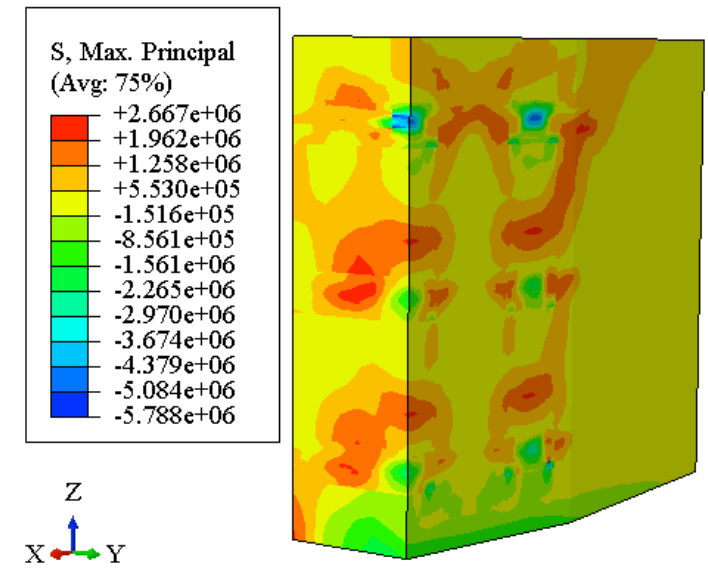

Fig. 16. Stress nephogram of the concrete slab along the vertical section

Figures 14 to 16 show that the concrete behind the shear key is the first to reach the tensile strength. The tensile stress spread from the back of this shear key to its rear. When the shear force of the I-beam was transmitted to the concrete through the shear key, the shear force pressed the concrete within the pressure-bearing range of shearing force to generate compressive strain. The concrete around the shear key prevented the deformation and was subject to tension.
Figure 17 shows the main tensile stress nephogram of the bottom contact surface between the concrete slab and I-beam before the cracking at $0.315 \mathrm{Pu}$. The tensile stress area in Figure 17 was located behind the lower shear key and the side of the wing plate. The largest pressure on the concrete was observed before the lower shear key and the pressure transmission range.

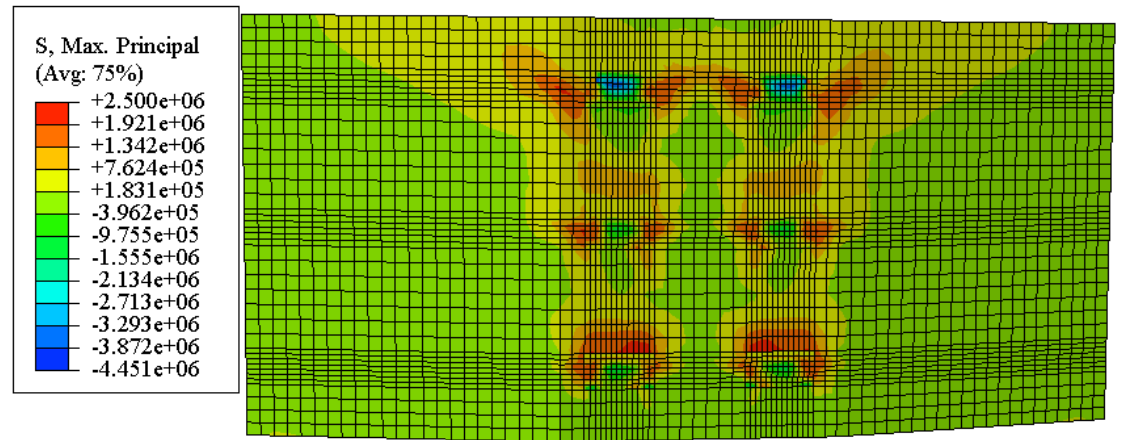

Fig. 17. Main tensile stress nephogram of the bottom contact surface between the concrete slab and I-beam

\subsubsection{Stress state of the shear key when yielding}

The shear key yielded when the load size reached 13,500 kN and when loaded to $0.7 \mathrm{Pu}$. Figures 18 to 20 show the stress nephograms of the concrete slab and shear key at $0.7 \mathrm{Pu}$.

Figures 18 and 19 show that upon reaching the yield load of the shear key, the compressive strain of the concrete compression zone before the shear key is $1.169 \times 10^{-3}$. Meanwhile, small area of concrete had a compressive strain of $1.988 \times 10^{-3}$. The concrete in this area was located closest to the front of the shear key and developed upward from the root of the shear key. The strain in this area nearly reached the peak strain of the concrete. As shown in Figure 20, the root of the wing plate of the shear key reached the yield stress with a stress value of $345 \mathrm{MPa}$. The root area of the shear key wing was the first to yield, and the shear key resisted shear at the web and wing. The shear resistance area of the wing was smaller than that of the web and had the largest shearing force. The shear force was initially transmitted from the root to the top of the shear key. Therefore, the stress at the root of the shear key was the largest.

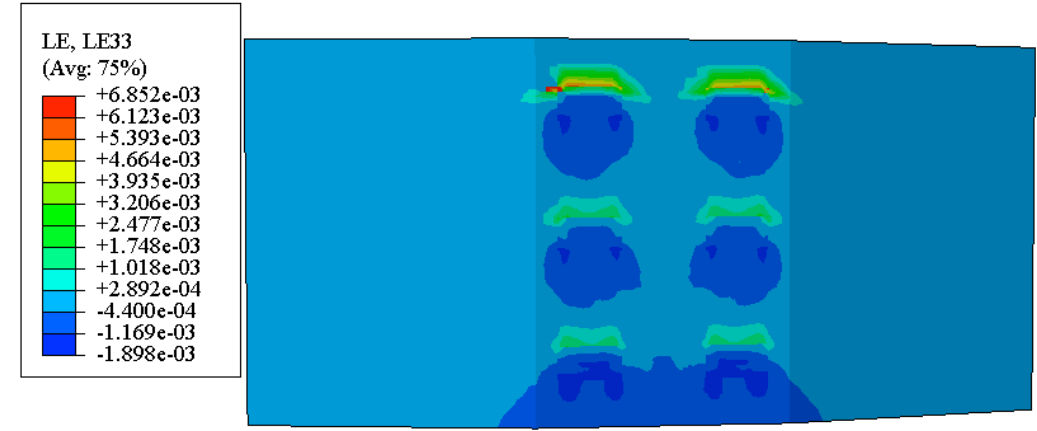

Fig. 18. Strain nephogram of the bottom contact surface of the concrete slab and I-beam 
Jiuqun Mao, Jiazhi Zhuang, Peng Duan, Yingkun Xie and Mingzhen Li/

Journal of Engineering Science and Technology Review 12 (1) (2019) 163 - 172

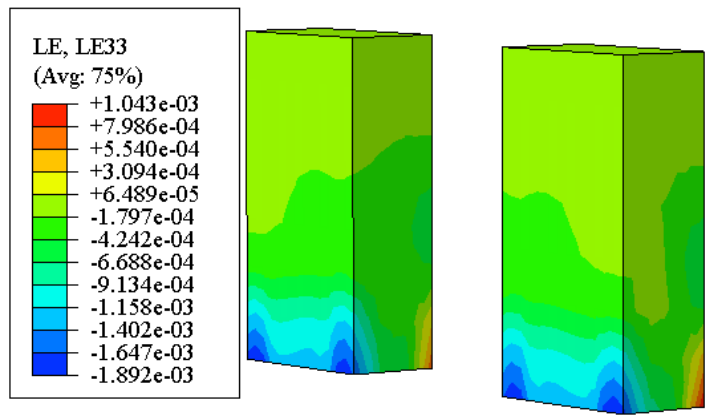

Fig. 19. Strain nephogram of the filling material along the opening direction of the shear key

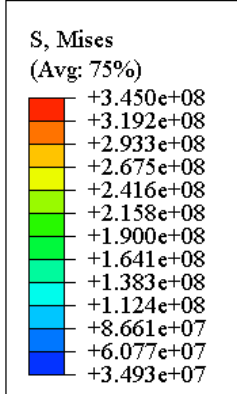

Fig. 20. Stress nephogram of the shear key

\subsection{Strain distribution of the concrete slab}

The strain along the longitudinal direction of the concrete slab was then examined. Namely, the transmission direction of the shear force and the direction along the $\mathrm{Z}$ coordinate axis in the model. In order to understand the strain distribution in areas with and without shear key on the concrete slab, two paths were defined in the model as shown in Figures 21 and 22. Path1 has a shear key in the longitudinal direction, while Path2 has no shear key in the longitudinal direction. Figure 23 shows the strain distribution of the concrete slab without shear keys in the longitudinal direction (the positive value indicates tensile strain while the negative value indicates compressive strain).

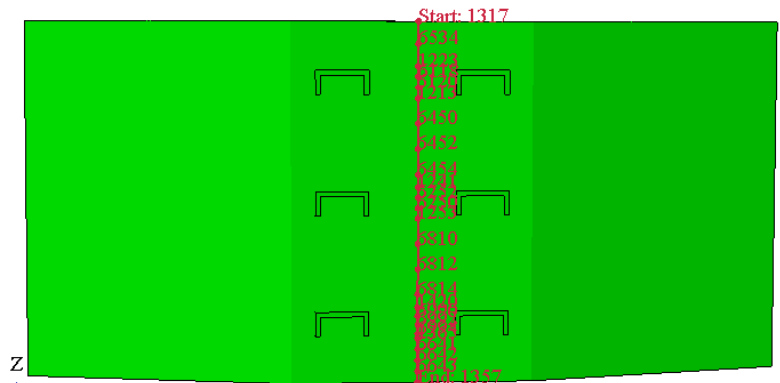

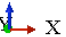

Fig. 21. Path1 along the path without a shear key

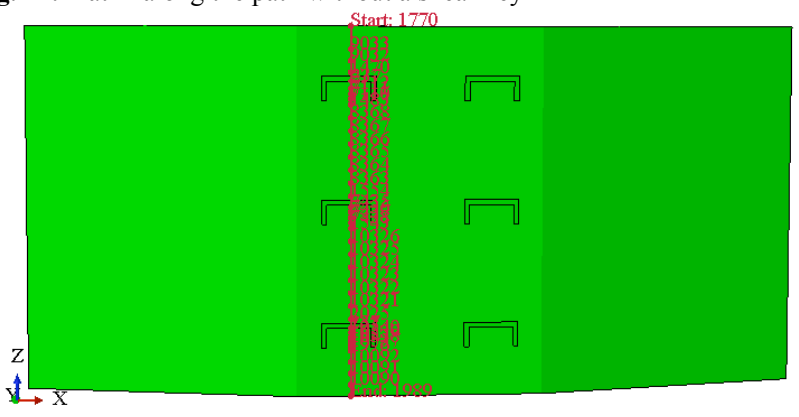

Fig. 22. Path 2 along the path with a shear key

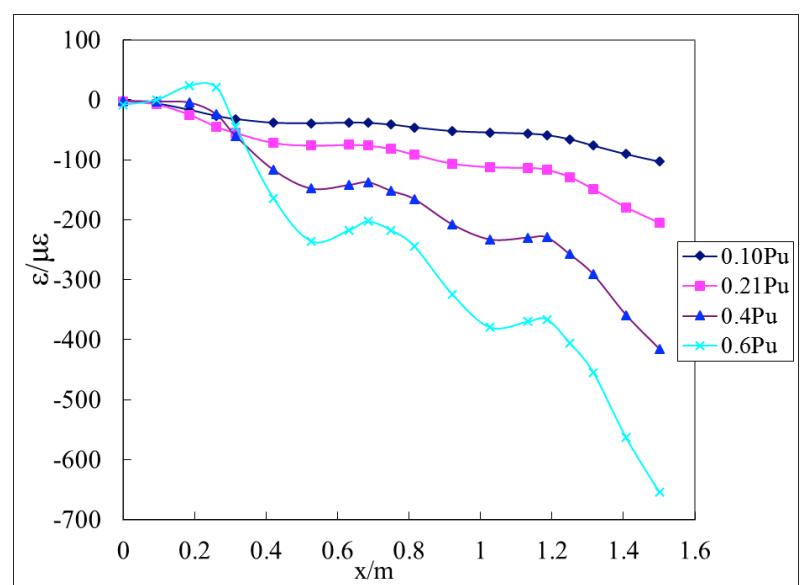

Fig. 23. Distribution of strain along the longitudinal centerline of the concrete slab

The distribution of strain along the longitudinal centerline of the concrete slab shows that when the load is smaller than $0.4 \mathrm{Pu}$, the strain of the concrete slab along the longitudinal centerline had a smooth curve and increased linearly from top to bottom. Meanwhile, when the load exceeds $0.4 \mathrm{Pu}$, the increase in strain along with the load had a wavy curve. Given that the stress was transmitted from the I-beam to the concrete precast plate through the shear key, the area of the shear key of the concrete precast plate was much larger than the stress of the area without the shear key. As a result, the force transmission in the longitudinal direction of the concrete plate was uneven and showed a wavy distribution. The distribution became more obvious as the load increased, and the load $\mathrm{P}$ was transmitted from top to bottom by three rows of shear keys. The concrete located closest to the support had the largest axial force and compressive strain.

The strain distributions in areas with and without shear keys in the longitudinal direction of the concrete slab were compared at load levels of $0.21,0.4$, and $0.6 \mathrm{Pu}$ in Figures 24 to 26 , respectively. 
Jiuqun Mao, Jiazhi Zhuang, Peng Duan, Yingkun Xie and Mingzhen Li/

Journal of Engineering Science and Technology Review 12 (1) (2019) 163 - 172

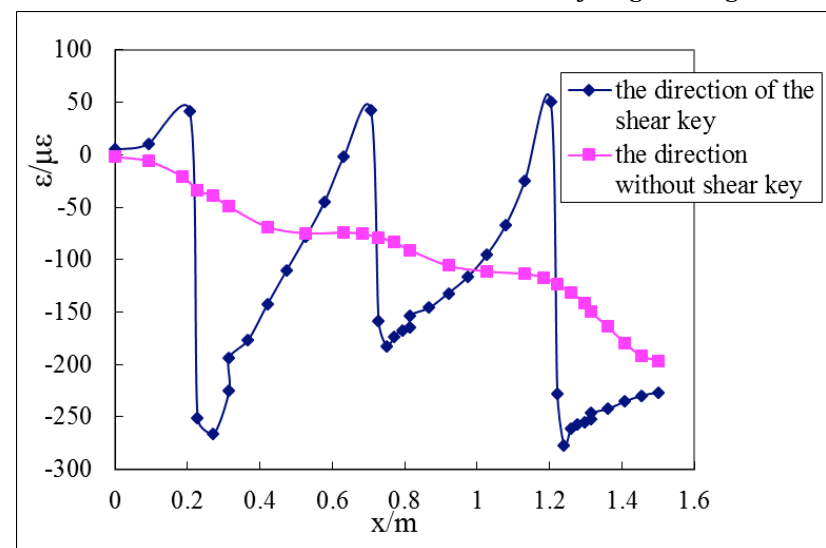

Fig. 24. Strain distribution along the longitudinal direction of the concrete slab at $0.21 \mathrm{Pu}$

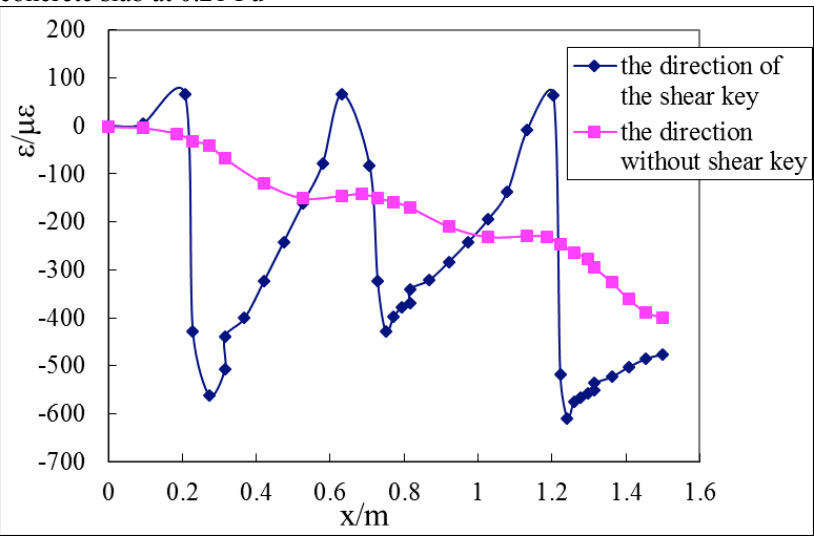

Fig. 25. Strain distribution along the longitudinal direction of the concrete slab at $0.4 \mathrm{Pu}$

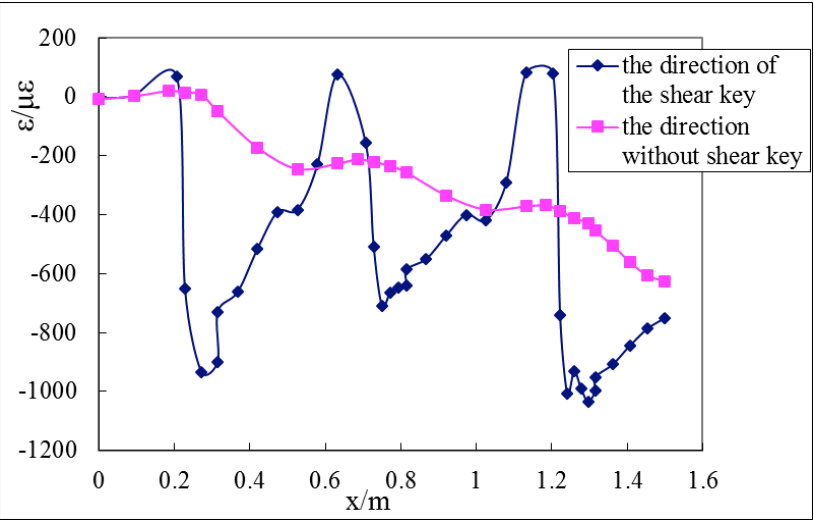

Fig. 26. Strain distribution along the longitudinal direction of the concrete slab at $0.6 \mathrm{Pu}$

The distribution of strain along the longitudinal direction of the concrete plate with and without the shear key shows that

(1) the strain distribution of the precast concrete slab along the longitudinal direction is non-uniform and exhibits a wave form;

(2) in the longitudinal strain distribution of the concrete slab, the concrete located near the shear key a greater strain, while the concrete located far from the shear key had a smaller strain. The strain distribution law of the concrete slab in the area with shear key was also very obvious. The maximum compressive strain was observed in the area surrounded by the shear key; and

(3) the concrete in the area with the shear key had tensile stress that was directly proportional to the load. When the shear force of the I-beam was transmitted to the concrete through the shear key, the concrete in the pressure-bearing range of the shearing force was pressed and compressive strain was generated. The concrete around the shearing pressure bearing range prevented the deformation and was subject to tension, thereby leading to tensile strain.

\section{Conclusions}

To understand the mechanical response characteristics of the steel-concrete composite beam with steel box and precast deck, finite element analysis was combined with the experimental method to develop the experimental model of the shear key of steel-concrete composite beam with steel box and precast deck and to analyze its mechanical properties, including force transmission mechanism, stress state, and strain distribution. The coupling relationship between the steel box girder and precast bridge deck under the shear key was then explored. The following conclusions could be drawn :

(1) As the load increases, the compressive stress of the concrete slab gradually expands from the root of the shear key in an arched manner and eventually forms an elliptical table.

(2) After the transmission of shear force by the shear keys in the upper, middle, and lower rows, the lower and middle shear keys showed the largest and smallest loads, respectively. The load on a single shear key is inversely proportional to its distance from the loading point.

(3) The concrete slab has a cracking load of $0.47 \mathrm{Pu}$. The crack initially appears in the concrete area behind the shearing key and expands to the rear of the shearing key along with an increasing load.

(4) The shear key has a yield load of $0.7 \mathrm{Pu}$, and the root at the wing of the shear key is the first to yield. The shear key resists the shear together at the web and wing. Although the wing plate has a smaller shear resistance area compared with the web, its shear force is the largest. Moreover, the shear force is initially transmitted from the root to the top of the shear key, thereby producing the largest stress at the root of the shear key.

This study also combines the element analysis method with the experimental method to understand the mechanical response characteristics of a steel-concrete composite beam with steel box and precast deck as a new combined shear connection structure. The above conclusions can provide references for optimizing the design of bridges with steelconcrete composite girders. However, due to the lack of measured data in the indoor push-out test, these data need to be introduced and corrected to further examine the force bearing mechanism of the shear key of steel-concrete composite beam with steel box and precast deck.

\section{Acknowledgements}

This work was supported by the Youth Research Fund Project of Chongqing Jianzhu College (Analysis of Mechanical Response of Steel Box-Precast Concrete Slab Shear Connection Structure)

This is an Open Access article distributed under the terms of the Creative Commons Attribution License

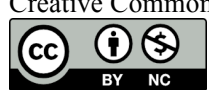




\section{References}

1. Ding Faxing, Ni Ming, Gong Yongzhi, Yu Zhiwu, Zhou Zheng, Zhou Linchao, "Experimental study on the slip performance of stud shear connectors and calculation of shear capacity". Journal of Building Structures, 35(09), 2014, pp. 98-106.

2. Lin Zhaofei, Liu Yuqing, "Peak Slip and Shear-Slip Constitutive Relationship of Welded Joints". Journal of Tongji University(Natural Science), 42(07), 2014, pp. 1006-1010.

3. Chen Y T, Zhao Y, West J S, et al, "Behaviour of steel-precast composite girders with through-bolt shear connectors under static loading”. Journal of Constructional Steel Research, 103, 2014, pp. $168-178$.

4. Ministry of Housing and Urban-Rural Development of the People's Republic of China, "Steel Structure Design Specification: GB50017-2017”. Beijing: China Planning Press, China, 2017, pp.132-133.

5. Li Chengjun, Zhou Zhixiang, Su Ci, Fan Liang, "Experimental study on prefabricated combined shear nails". Bridge Construction, 45(05), 2015, pp. 60-65.

6. Xu C, Sugiura K, "Analytical investigation on failure development of group studs shear connector in push-out specimen under biaxial load action". Engineering Failure Analysis, 37, 2014, pp. $75-85$.

7. Li Chengjun, Zhou Zhixiang, Huang Yayi, Fan Liang, "Study on Shear Capacity of Assembled Composite Beam Shear Studs". Journal of Chinese Highway Society, 30(03), 2017, pp. 264-270.

8. Kong Jie, "Research on shear resistance of high strength bolts used to join steel-concrete composites". Master thesis of Southeast University, China, 2017, pp.23-26.

9. Shim C S, Chang S P, "Cracking of continuous composite beams with precast decks". Journal of Constructional Steel Research, 59(2), 2003, pp. 201-214.

10. Fan Liang, Li Xiao, Dong Rongqiang, "Study on Shear Test of Shear Force Group of Steel Box-Concrete Combination Structure with Hole Stiffener Ribs". Science Technology and Engineering, 17(14), 2017, pp. 256-261.

11. Lin Z, Liu Y, He J, "Behavior of stud connectors under combined shear and tension loads". Engineering structures, 81, 2014, pp. 362-376.

12. Xu C, Sugiura K, Masuya H, et al, " Experimental study on the biaxial loading effect on group stud shear connectors of steelconcrete composite bridges" Journal of bridge engineering, 20(10), 2014, pp. 04014110.

13. Zhu Bing, Wang Xuewei, "Experimental study on PBL shear bond of steel-mixed composite girder bridge considering transverse prestress effect". Journal of Southwest Jiaotong University, 51(04), 2016, pp. 621-631.
14. Shim C S, Lee P G, Yoon T Y, "Static behavior of large stud shear connectors". Engineering structures, 26(12), 2004, pp. $1853-1860$.

15. Tian Shanpo, "Study on calculation method of shear connectors for steel-mixed composite beams". Journal of Railway Engineering Society, 31(08), 2014, pp. 56-61.

16. Kuhlmann U, Breuninger U, "Behaviour of horizontally lying studs with longitudinal shear force". In: Composite Construction in Steel and Concrete IV, Banff, Canada: ASCE, 2002 pp. 438449.

17. Veljkovic M, Johansson B., "Residual static resistance of welded stud shear connectors". In: Composite Construction in Steel and Concrete V, Berg-en-Dal, South Africa: ASCE, 2006, pp. 524533.

18. Su Qingtian, Li Yu, "Study on Shear Capacity of High Strength Mortar Group Nail Connections". Journal of Tongji University(Natural Science), 43(05), 2015, pp. 699-705.

19. Topkaya C, Yura J A, Williamson E B, "Composite shear stud strength at early concrete ages". Journal of Structural Engineering, 130(6), 2004, pp. 952-960.

20. Yuan Aimin, Fu Jundong, Cheng Leike, Lu Rongwei, "Shear performance test of shear bond of precast bridge joints". China Journal of Highway and Transport, 31(12), 2018, pp. 81-87.

21. Sun Wenzhao, "Research on ultimate limit state and ultimate bearing capacity of embedded pbl shear bond". Master thesis of Southwest Jiaotong University, China, 2017, pp.55-59.

22. Yang Sen, "Experimental and theoretical study on shear behavior of frp profile-concrete composite beams". Master thesis of Zhengzhou University, China, 2018, pp.78-81.

23. Classen M, "Limitations on the use of partial shear connection in composite beams with steel T-sections and uniformly spaced rib shear connectors". Journal of Constructional Steel Research, 142 2018, pp. 99-112.

24. Lowe D, Das R, Clifton C, "Clifton C. Characterization of the splitting behavior of steel-concrete composite beams with shear stud connection". Procedia Materials Science, 3, 2014, pp. 21742179.

25. Cao Shengtao, Li Zhishan, "A uniaxial elastoplastic damage constitutive model for confined concrete". Engineering Mechanics, 34(11), 2017, pp. 116-125.

26. Xu Lihua, Li Changning, Li Biao, Chi Yin, Huang Biao, "Onedimensional elastoplastic damage constitutive model of steel fiber reinforced concrete under cyclic compression". China Civil Engineering Journal, 51(11), 2018, pp. 77-87. 